International Journal of Advanced Studies in Humanities and Social Science (IJASHSS) Available online at http://www.ijashss.com

Volume 8, Issue 1 (2019) pp. 91-103

Original Article

\title{
The Comparative Study of Ownership Structure Effects (Mix and Concentration) on the Value of Companies Listed in Tehran Stock Exchange (Iran) and Bombay Stock Exchange (India)
}

\author{
Hossein Ali Jalali1 ${ }^{*}$, Asghar Asadi², Seyed Yosef Ahadi Serkani² \\ ${ }^{1}$ Department of Accounting, Faculty of Accounting, Islamic Azad University, Firoozkouh \\ Branch, Tehran, Iran \\ ${ }^{2}$ Assictant Professor, Department of Accounting, Islamic Azad University, Firoozkouh \\ Branch, Tehran, Iran
}

Received: 24 October 2018, Revised: 05 December 2018, Accepted: 20 December 2018

\begin{abstract}
The present is a comparative study investigating the effect of ownership structure (concentration and mix) on the value. It is an important issue in financial management texts and financial management discussions of companies. The present work is aimed to find the effect of ownership concentration and shareholding mix of a company in its value. The statistical population of the study includes all companies of pharmaceuticals and food industry, automobiles and auto parts, electricity, oil and gas, industry and mine except than investing and holding companies listed in Tehran stock exchange and Bombay stock exchange during 2006-2010. Based on the findings, there is a positive and significant relation between ownership concentration (natural and institutional) and the value of companies listed in Tehran stock exchange and Bombay stock exchange while there is no significant relation between ownership type (natural and institutional) and the value of companies listed in Tehran stock exchange. Further, in Bombay stock exchange, a negative and significant relation is observed between institutional ownership and the value of companies and also a positive and significant relation between natural ownership and the value of companies.
\end{abstract}

Keywords: Book-Market Value Ratio, Company Size, Financial Leverage, Revenue Growth Rate of Sale, Systematic Risk, Stock Cash Return, Total Price Index Changes.

\section{Introduction}

The relation between ownership structure (including concentration and mix ownership) and the value of company is always considered by financial researchers. For the first time, Berle and Means (1932) discovered the reverse relation between shareholders dispersion and the performance of institutes.
Although their findings were challenged by Demsetz (1983), their study was the beginning of many researches and discussions that were conducted by researchers in different countries with economic bases and different development levels. During the recent years, various studies have been done on ownership 
structure based on two main approaches including the effect and the role of ownership type as well as concentration in efficiency and value of companies.

In the present study, it was investigated that whether ownership structure or the aspects of shareholding mix and ownership concentration of companies listed in Tehran stock exchange as well as Bombay stock exchange (as independent variable) affects the value of these companies or not. In this regards, two aspects of concentration and mix were considered for independent variable of ownership structure. Tow indices of institutional and natural for shareholding mix, and one index and some control variables were considered for ownership concentration. To determine the direction and amount of the investigate defect and its significance was tested using regression method.

\section{Statement of the Problem}

From the 1930s, based on the research of Berle and Means (1932) and Coase (1937), economists tended to examine the effects of ownership separation and controlling trade companies. Different objectives of investors and Board members create some issue as representativeness problems. Corporate governance studies investigate the mechanisms used by investors to control companies to decrease these problems. Usually, the methods which can be used by investors to align the interests of internal personnel (managers and Board) with their own interests are divided into two types of external and internal. For instance, the external mechanisms include market to control company and the internal mechanisms involve wage system and management wage, internal individuals' management and ownership concentration. The external strategies are of specific importance in "anglo-saxon culture" and legal systems experienced dispersed ownership structure. The internal mechanisms are common in other markets including Iran`s market.

While some of studies attempted to find the positive relation between ownership concentration and performance, Demsetz (1983) stated that no relation can be between ownership structure and the value of company. He theoretically discussed that ownership concentration is the internal result of costs balance (such as risk) and benefits (such as supervision). To ignore the relation, individual should regard ownership structure as the result of a set of decisions reflecting the effect of shareholders and transferable activity in stock market. Therefore, tendency to ownership is decreased in case of proposing a general suggestion or decision based on selling a great amount of stock. Similarly, the ownership of great parts of stock or purchasing stock of a company can increase ownership concentration.

The feature of main shareholder is another aspect which is discussed in investigation of the effect of ownership structure as control mechanism. There are many studies regarding supervisory role of state, institutional and individual investors. Some studies about ownership type indicate the improvement in institutional value changing their ownership type or doing privatization operations. The difference in managerial and supervisory incentives, political objectives and social commitments of state units mostly cause the expectation that these units have had a weaker performance compared to the other institutes. On the other hand, institutional and corporative owners may show a better performance due to stronger incentives to 
gain benefit and more access to information.

In the present study, the effect of shareholding mix and ownership concentration in the value of Iranian and Indian companies has been examined. To investigate the value of companies, $Q$ Tobin variable is considered and shareholders dispersion dimensions and ownership concentration are also considered for ownership structure. So, "shareholding mix" and "ownership concentration" are independent variables and "Tobin variable" as the index of companies`value is dependent variable. It is attempted to discover the presence of such effect and if the relation is positive and negative and also what is the direction and degree of the relation.

\section{The Research Objectives}

The present research is an applied study attempting to investigate the relation of variables in exchange market and determine the relations as well as provide some recommendations to promote the market efficacy. It is also a nonexperimental descriptive study in terms of data gathering method and a regression analysis with the aim of finding the relation between tested variables. It is aimed to find the effect of various ownership structures (ownership concentration and shareholding mix) of company in the value of companies listed in Iran stock exchange and Bombay stock exchange in order to specify the relation between two variables to be taken into consideration by managers, investors and other people in their financial and investing decisions.

\section{The Research Hypothese}

\section{Main Hypotheses}

There is a significant relation between ownership concentration and the value of companies listed in Tehran`s stock exchange.

There is a significant relation between ownership concentration and the value of companies listed in Bombay`s stock exchange.

There is a significant relation between ownership type and the value of companies listed in Tehran`s stock exchange.

There is a significant relation between ownership type and the value of companies listed in Bombay`s stock exchange.

\section{Secondary Hypotheses}

There is a significant relation between ownership concentration degree (institutional ownership) and the value of companies listed in Tehran`s stock exchange.

There is a significant relation between ownership concentration degree (natural ownership) and the value of companies listed in Tehran`s stock exchange.

There is a significant relation between ownership concentration degree (institutional ownership) and the value of companies listed in Bombay`s stock exchange.

There is a significant relation between ownership concentration degree (natural ownership) and the value of companies listed in Bombay`s stock exchange.

There is a significant relation between ownership type (institutional ownership) and the value of companies listed in Tehran`s stock exchange.

There is a significant relation between ownership type (natural ownership) and the value of companies listed in Tehran`s stock exchange.

There is a significant relation between ownership type (institutional ownership) 
and the value of companies listed in Bombay's stock exchange.

There is a significant relation between ownership type (natural ownership) and the value of companies listed in Bombay`s stock exchange.

\section{Research Background}

Gumperz et al. (2003) studied the relation of corporate governance and corporate performance. They concluded that companies with better corporate governance have better performance, higher value and higher stock return.

Capopolus and Lozarito (2007) also investigated the effect of ownership structure in corporate performance using the information of 175 Greek companies. The findings revealed a positive and significant relation between concentrated ownership structure and company`s profitability.

Wang et al. (2009) explored the effect of corporate governance features in Chinese companies' performance. They used two approaches of corporate governance. Firstly, they examined the effect of each features of corporate governance in companies' performance and then, all features of corporate governance were investigated. As they reported, companies with better corporate governance showed better performance and higher value. Also, a positive and significant relation was found between ownership concentration, institutional investing, and state ownership and the market value.

Namazi and Kermani (2008) worked on the effect of ownership structure in the performance of companies listed in Tehran`s stock exchange during 2003-207. Based on the study, they observed a significant relation between ownership structure of companies and their performance.
Hassas Yegane et al. (2008) investigated the relation between institutional investing and the company value. They used linear multiple regression. Based on the findings, a positive and significant relation was observed between institutional investing and the company value.

Smith et al. (2011) conducted a study on "corporate strategies and company value" investigating the relation of corporate strategies and company value in 6663 observations (company-year) among 22 developed countries using Q Torbin during 2003-2007. The data of corporate strategy used in testing hypotheses was received from international index of corporate strategy from GMI website. The findings showed a positive and significant relation between all features of corporate strategy as well as social behavior of companies with company value.

Chung and Sun (2008) believed that after financial scandals, investors focused the issue that duality of managing director's duty may endanger safekeeping of managing director in financial reporting. They also believed that duality of managing director's duty potentially increase the risk of being final decision maker in financial reporting that as a result, it may increase the company value. The presented some evidence about the relation between corporate strategy and institutional stock ownership. Based on the evidence, company`s stock ratio held by institutional investors increase the quality of governance structure. Their findings were consistent with this fact that institutional investors tend to the stock of companies with good governance structure to estimate managerial consulting responsibility.

Richner and Dalton (1991) also revealed that companies with double-task director of board members had better 
performance compared to the companies with separated roles and responsibilities.

Burg and Smith (1978) based on their findings claimed that there was no relation between the performance of companies with separated roles of managing directors and head of board of directors and the indices of the performance of companies with non-separated roles.

Moloudi (2009) investigated the relation between corporate strategy and created value for shareholders. In companies with created value, the findings revealed a direct and significant relation between director of board's reward and created value for shareholders. Also, no significant relation was observed between institutional shareholders ownership and managing director's duty separation from head or assistant and the created value for shareholders.

\section{The Research Model}

In the present study, regression method is used to determine the relation between dependent and independent variable. Further, book-market value ratio, company size, financial leverage, revenue growth rate of sale, systematic risk, stock cash return, total price index changes are considered to control the effect of other factors in company value.

Considering the operational definition of dependent variable and independent variables, the base model of the research is tested as follow. The model is tested with the presence of estimation controlling variables:

$\mathrm{Q}_{i t}=\mathrm{B}_{0}+\mathrm{B}_{1} \mathrm{fr}_{i t}+\mathrm{B}_{2}$ con $i t+\mathrm{B}_{3} \mathrm{lev} i t+\mathrm{B}_{4}$ beta $_{i t}+\mathrm{B}_{5}$ grow $_{i t}+\mathrm{B}_{6} \mathrm{rm}_{i t}+\mathrm{B}_{7}$ size $_{i t}$

Where:

$\mathrm{Q}$ it Tobin variable of company $=\mathrm{i}$ at $\mathrm{t}$ time fra ${ }_{I}$ ownership type of company $=\mathrm{i}$ at $\mathrm{t}$ time
Con it ownership concentration of company

$=\mathrm{i}$ at $\mathrm{t}$ time

Lev it financial leverage of company $=\mathrm{i}$ at $\mathrm{t}$ time

Beta ${ }_{\text {it }}$ systematic risk of company $=\mathrm{i}$ at $\mathrm{t}$ time

Grow it sale growth rate of company $=\mathrm{i}$ at $\mathrm{t}$ time

$R m$ it =stock cash return and total price index changes $=\mathrm{i}$ at $\mathrm{t}$ time

\section{Methodology}

In the present research, "shareholding mix" and "ownership concentration" are considered as independent variables and "Tobin variable" is considered as dependent variable. Shareholding mix includes two indices of the percentage of institutional shareholding ownership and the percentage of natural shareholding ownership. Tobin variable is a ratio which is used as value criterion. The mentioned ratio is obtained as the result of dividing properties market value on their replacement cost. Regression method is used to determine the relation between dependent and independent variable. Further, book-market value ratio, company size, financial leverage, revenue growth rate of sale, systematic risk, stock cash return, total price index changes are considered to control the effect of other factors in company value.

\section{Statistical Population and Sample}

\section{Statistical Population in Iran}

The statistical population in Iran includes all companies of pharmaceuticals and food industry, automobiles and auto parts, electricity, oil and gas, industry and mine except than investing and holding companies listed in Tehran stock exchange and during 2006-2010. 


\section{Statistical Population in Bombay}

The statistical population in Bombay includes all companies listed in group A of Bombay stock exchange in pharmaceuticals and food industry, automobiles and auto parts, electricity, oil and gas, industry and mine except than investing and holding companies during 2006-2010. The companies listed in group A are the most active companies with the highest capital, widest transactions, highly sold stock, high profitability, and SENSEX exchange index. This index is globally well known index including 30 corresponding stock with 12 main industries and is computed based on free floating share. All the companies in this group should be matched with the necessary conditions of the group.

\section{Data Gathering Method}

The data of the study has been gathered using library method by referring to library sources such as books, magazines, seasonal, quarterlies, and research centers publications, theses, websites, etc. The informational sites of Tehran stock exchange and Bombay stock exchange have also been used. Documentary statistics of stock organization and annual accounting reports of companies such as Board`s reports to annual general association and financial statements and notes have been used to gather data of
Tehran stock exchange. Tadbir pardaz software has also been used from informational sites of stock exchange.

In order to gather the data of Bombay stock exchange, annual reports, BSE and information site of each companied listed in group A have been used.

The collected data has been analyzed after comparison and homogenizing and classification through Excel software.

\section{Data Analysis}

In the following table, central indices such as mean, median and dispersion indices including standard deviation and skewness have been computed for the variables. Greater value of median relative to mean indicates large points since mean is influenced by these values. In these cases, the skewness of data distribution tends towards right side. For the sample, variables of $\mathrm{Q}_{i t}$, beta $i$, and size $i t$ have the ight skewness. In some cases, skewness is towards left side. None of the variables of the research has left skewness and the mean and median values are close indicating a symmetric distribution. This feature is of high importance since symmetry is a feature of normal distribution. The logarithm of dependent variable with the value of skewness for Iranian and Indian companies is $1 / 06$ and $0 / 99$, respectively that is very similar to normal distribution.

Table 1. Descriptive statistics of variables existing in the model of Iran and India stock exchange

\begin{tabular}{ccccccccc}
\hline Maximum & Minimum & kortosis & skewness & $\begin{array}{c}\text { Standard } \\
\text { deviation }\end{array}$ & Median & Mean & number & variables \\
\hline $8 / 68$ & $0 / 21$ & $8 / 65$ & $2 / 95$ & $1 / 50$ & $1 / 29$ & $1 / 76$ & 186 & $Q_{i t}$ \\
$2 / 16$ & $-0 / 43$ & $1 / 19$ & $1 / 06$ & $0 / 53$ & $0 / 26$ & $0 / 38$ & 186 & Lnq $_{i t}$ \\
$99 / 90$ & $29 / 00$ & $2 / 91$ & $-1 / 47$ & $13 / 40$ & $81 / 65$ & $79 / 06$ & 186 & Fr $_{i t}$ \\
8840 & 216 & $0 / 69$ & $0 / 93$ & 1790 & 3268 & 3603 & 186 & Con $_{i t}$ \\
$1 / 08$ & $0 / 04$ & $0 / 96$ & $-0 / 48$ & $0 / 16$ & $0 / 65$ & $0 / 64$ & 186 & Lev $_{i t}$ \\
$1 / 19$ & $-0 / 88$ & $2 / 96$ & $0 / 75$ & $0 / 30$ & $0 / 18$ & $0 / 21$ & 186 & Grow $_{i t}$ \\
$0 / 90$ & $-0 / 06$ & $65 / 03$ & $7 / 55$ & $0 / 10$ & $0 / 00$ & $0 / 02$ & 186 & Beta $_{i t}$ \\
$0 / 32$ & $0 / 25$ & $-0 / 07$ & $1 / 21$ & $0 / 03$ & $0 / 25$ & $0 / 26$ & 186 & Rm $_{i t}$ \\
& & & & & & & & 96|Page \\
\hline
\end{tabular}




\begin{tabular}{|c|c|c|c|c|c|c|c|c|}
\hline $33 / 98$ & $24 / 02$ & $2 / 24$ & $1 / 25$ & $1 / 69$ & $27 / 38$ & $27 / 54$ & 186 & Size $_{i t}$ \\
\hline $45 / 19$ & $0 / 38$ & $7 / 09$ & $2 / 83$ & $9 / 02$ & $2 / 57$ & $5 / 70$ & 162 & $Q_{i t}$ \\
\hline $3 / 81$ & $-0 / 97$ & $0 / 90$ & $0 / 99$ & $0 / 99$ & $0 / 94$ & $1 / 11$ & 162 & $L n q_{i t}$ \\
\hline $84 / 91$ & $1 / 34$ & $0 / 36$ & $0 / 54$ & $15 / 94$ & $28 / 17$ & $29 / 33$ & 162 & Fr ${ }_{i t}$ \\
\hline $1530 / 35$ & $2 / 08$ & $0 / 01$ & $0 / 85$ & $368 / 39$ & $384 / 61$ & $466 / 24$ & 162 & Con $_{i t}$ \\
\hline $1 / 13$ & $0 / 03$ & $0 / 56$ & $0 / 07$ & $0 / 20$ & $0 / 49$ & $0 / 50$ & 162 & $\mathrm{LeV}_{\text {it }}$ \\
\hline $1 / 07$ & $-0 / 88$ & $3 / 85$ & $-0 / 06$ & $0 / 27$ & $0 / 20$ & $0 / 20$ & 162 & Grow $_{\text {it }}$ \\
\hline 374 & -1239 & $0 / 06$ & $-0 / 17$ & $291 / 60$ & $276 / 95$ & $-305 / 75$ & 162 & Beta $_{i t}$ \\
\hline 18173 & 5454 & $-1 / 28$ & $-0 / 19$ & 4365 & 12539 & 12290 & 162 & $R m_{i t}$ \\
\hline $31 / 28$ & $22 / 53$ & $2 / 11$ & $1 / 09$ & $1 / 52$ & $25 / 46$ & $25 / 67$ & 162 & Size $_{i t}$ \\
\hline
\end{tabular}

\section{Models`Estimation}

\section{Institutional Ownership $\quad$ Model's
Estimation $\quad\left\{\begin{array}{l}H_{0}: \beta_{1}=\beta_{2}=\ldots=\beta_{7} \\ H_{1}: \beta_{i} \neq 0 \text { i }=1,2, \ldots, 7\end{array}\right.$ \\ The given model is as follow: \\ $\mathrm{Q}_{i t}=\mathrm{B}_{0}+\mathrm{B}_{1} \mathrm{X} 1_{i t}+\mathrm{B}_{2}$ con $i t+\mathrm{B}_{3} \mathrm{lev} i t+\mathrm{B}_{4}$ \\ beta $_{i t}+\mathrm{B}_{5}$ grow $_{i t}+\mathrm{B}_{6} \mathrm{rm}_{i t}+\mathrm{B}_{7}$ size $_{i t}$ \\ $\left\{\begin{array}{lr}\boldsymbol{H}_{\mathrm{O}}: & \text { There is no significant } \\ \boldsymbol{H}_{1}: & \text { model } \\ & \text { There is a significant } \\ \text { model }\end{array}\right.$}

The null hypothesis and the alternative hypothesis are as follows:
As shown, the results of regression analysis have been presented in Table 2 .

Table 2. The results of ANOVA test

\begin{tabular}{ccccccc}
\hline Sig & F value & Mean of squares & $\begin{array}{c}\text { Degree of } \\
\text { freedom }\end{array}$ & Sum of squares & Changes source & Country \\
\hline \multirow{3}{*}{0.00} & \multirow{2}{*}{26.55} & 3.83 & 7 & 26.81 & Regression & \\
& & 0.14 & 178 & 25.68 & Residual & Iran \\
\hline
\end{tabular}

\section{Testing the First Secondary Hypothesis of the First Hypothesis}

"There is a significant relation between ownership concentration degree (institutional ownership) and the value of companies listed in Tehran`s stock exchange".

T-value for the degree of ownership concentration is 2/39 (positive and significant). The significance level for the degree of ownership concentration is $0 / 02$ which is less than $0 / 05$. Therefore, the null hypothesis is rejected and the alternative hypothesis is confirmed; also, considering the fact that Beta is $0 / 14$, there is a significant and positive relation between ownership concentration and value. That is, the relation is positive and significant. The maximum value of VIF for the degree of ownership concentration is $1 / 21$ and the hypothesis is confirmed.

\section{Testing the First Secondary Hypothesis of the Third Hypothesis}

"There is a significant relation between ownership type (institutional ownership) and the value of companies listed in Tehran`s stock exchange".

T-value for the degree of ownership concentration is $0 / 45$ (insignificant). The significance level for the degree of ownership concentration is $0 / 66$ which is more than $0 / 05$. Therefore, the null 
hypothesis is confirmed and the alternative hypothesis is rejected; therefore, there is no significant relation between ownership type and value. The maximum value of VIF for the degree of shareholder's ownership is $1 / 32$, so the hypothesis is rejected.

\section{Testing the Secondary Hypotheses of the Second and Fourth Hypotheses}

For Indian hypotheses, t-value of institutional ownership for con itm, lev it, grow it, beta it, $r m$ it, and size it equal with $-Y / \mu V$ (negative and significant), 4/02 (positive and significant), 0/72 (insignificant), 1/02 (insignificant), 6/20 (positive and significant), - 0/64 (insignificant), and $7 / 19$ (positive and significant), respectively. T-value for latitude is $-6 / 01$ which is placed at the significance level of $95 \%$ indicating that the latitude value is significance. The value of co-linear index is low in all variables and its maximum value is $1 / 37$.

\section{Testing the First Secondary Hypothesis of the Second Hypothesis}

"There is a significant relation between ownership concentration degree (institutional ownership) and the value of companies listed in Bombay`s stock exchange".

T-value for the degree of ownership concentration is $4 / 02$ (positive and significant). The significance level for the degree of ownership concentration is $0 / 00$ which is less than $0 / 05$. Therefore, the null hypothesis is rejected and the alternative hypothesis is confirmed; therefore, there is a positive and significant relation between the degree of ownership concentration and value. The maximum value of VIF for the degree of shareholder's ownership is $1 / 92$, so the hypothesis is confirmed.

\section{Testing the First Secondary Hypothesis of the Fourth Hypothesis}

"There is a significant relation between ownership type (institutional ownership) and the value of companies listed in Bombay`s stock exchange".

T-value for the degree of ownership type is - 2/37 (negative and significant). The significance level for the degree of ownership concentration is $0 / 02$ which is less than 0/05. Therefore, the null hypothesis is rejected and the alternative hypothesis is confirmed; therefore, there is a negative and significant relation between ownership type and value. The maximum value of VIF for the degree of shareholder's ownership is $1 / 71$, so the hypothesis is confirmed.

\section{Natural Ownership Model`s Estimation}

The given model is as follow:

$\mathrm{Q}_{i t}=\mathrm{B}_{0}+\mathrm{B}_{1} \mathrm{X} 2_{i t}+\mathrm{B}_{2}$ con $i t+\mathrm{B}_{3}$ lev $i t+\mathrm{B}_{4}$ beta $i t+\mathrm{B}_{5}$ grow $i t+\mathrm{B}_{6} \mathrm{rm}_{i t}+\mathrm{B}_{7}$ size $i t$ The null hypothesis and the alternative hypothesis are as follows:

$$
\begin{aligned}
& \left\{H_{0}: \beta_{1}=\beta_{2}=\ldots=\beta_{7}\right. \\
& \left\{H_{1}: \beta_{i} \neq 0 \quad i=1,2, \ldots, 7\right. \\
& \left\{\begin{array}{l}
H_{0}: \\
H_{1}:
\end{array} \quad\right. \text { There is no significant } \\
& \text { There is a significant } \\
& \text { model }
\end{aligned}
$$

As shown, the results of regression analysis have been presented in table 3 .

Table 3. The results of ANOVA test

\begin{tabular}{lllllcl}
\hline Sig & F value & $\begin{array}{c}\text { Mean of } \\
\text { squares }\end{array}$ & $\begin{array}{c}\text { Degree of } \\
\text { freedom }\end{array}$ & $\begin{array}{c}\text { Sum of } \\
\text { squares }\end{array}$ & $\begin{array}{c}\text { Changes } \\
\text { source }\end{array}$ & Country \\
\hline 0.00 & 26.55 & 3.83 & 7 & 26.81 & Regression & Iran \\
& & 0.14 & 178 & 25.68 & Residual & \\
& & & 158 & 25.49 & Total & \\
\hline
\end{tabular}


For Iranian companies, the significance level of $\mathrm{F}$ is $0 / 000$ which is less than $0 / 05$ indicating that the null hypothesis is rejected at the significance level of $95 \%$. In other words, the model is significant at the significance level of $95 \%$.

For Indian companies, the significance level of $\mathrm{F}$ is also 0/000 which is less than $0 / 05$ indicating that the null hypothesis is rejected at the significance level of $95 \%$. In other words, the model is significant at the significance level of $95 \%$.

For Iranian companies, the value of multiple correlation coefficient and determination coefficient are $0 / 71$ and $0 / 51$, respectively. That is, about $51 \%$ of dependent variable changes are stated by independent and controlling variable. The value of Durbin Watson statistic is also $1 / 72$.

Further, for Indian companies, the value of multiple correlation coefficient and determination coefficient are $0 / 71$ and $0 / 50$, respectively. That is, about $50 \%$ of dependent variable changes are stated by independent and controlling variable. The value of Durbin Watson statistic is also $1 / 78$.

\section{Testing the Secondary Hypotheses of the First and Third Hypotheses}

For Iranian companies, as shown in above table, t-value of natural ownership for con itm, lev it, grow it, beta it, rm it, and size it equal with $-0 / 45$ (insignificance), 2/39 (positive an significant), $-5 / 74$ (negative and significant), 0/51 (insignificance), $3 / 39$ (positive an significant), 0/23 (insignificance), and 6/98 (positive and significant), respectively. The positive (direct) relation means that by their increasing, the value of dependent variable is also increased and the negative and significant relation means that by their decrease, the dependent variable is decreased subsequently. T-value for latitude is $-4 / 19$ which is placed at the significance level of $95 \%$ indicating that the latitude value is significance. The value of co-linear index (VIF) is low in all variables and its maximum value is $1 / 4$ (for size it).

\section{Testing the Second Secondary Hypothesis of the First Hypothesis}

"There is a significant relation between ownership concentration degree (natural ownership) and the value of companies listed in Tehran`s stock exchange".

T-value for the degree of ownership concentration is $2 / 39$ (positive and significant). The significance level for the degree of ownership concentration is $0 / 02$ which is less than $0 / 05$. Therefore, the null hypothesis is rejected and the alternative hypothesis is confirmed; therefore, considering the Beta value of $0 / 14$, there is a positive and significant relation between the degree of ownership concentration and value. The maximum value of VIF for the degree of shareholder's ownership is $1 / 21$, so the hypothesis is confirmed.

\section{Testing the Second Secondary Hypothesis of the Third Hypothesis}

"There is a significant relation between ownership type (natural ownership) and the value of companies listed in Tehran's stock exchange".

T-value for the degree of ownership concentration of natural shareholders is 0/45 (insignificant). The significance level for the degree of ownership concentration is $0 / 66$ which is more than $0 / 05$. Therefore, the null hypothesis is confirmed and the alternative hypothesis is rejected; therefore, there is no significant relation between ownership type and value. The maximum value of VIF for the degree of shareholder's ownership is $1 / 32$, so the hypothesis is rejected. 
Testing the Secondary Hypotheses of the Second and Fourth Hypothesis

For Indian companies, t-value of natural ownership for con itm , lev it, grow it, beta it, $\mathrm{rm}$ it, and size it equal with $2 / 37$ (positive an significant), 4/02 (positive an significant), 0/72 (insignificant), 1/02 (insignificance), 6/20 (positive an significant),- 0/64 (insignificance), and 7/19 (positive and significant), respectively. T-value for latitude is $-6 / 01$ which is placed at the significance level of 95\% indicating that the latitude value is significance. The value of co-linear index (VIF) is low in all variables and its maximum value is $1 / 37$.

\section{Testing the Second Secondary Hypothesis of the Second Hypothesis}

"There is a significant relation between ownership concentration degree (natural ownership) and the value of companies listed in Bombay`s stock exchange".

T-value for the degree of ownership concentration is 4/02 (positive and significant). The significance level for the degree of ownership concentration is $0 / 00$ which is less than $0 / 05$. Therefore, the null hypothesis is rejected and the alternative hypothesis is confirmed; therefore, considering the Beta value of 0/00085, there is a positive and significant relation between the degree of ownership concentration and value. The maximum value of VIF for the degree of shareholder's ownership is $1 / 92$, so the hypothesis is confirmed.

\section{Testing the Second Secondary Hypothesis of the Fourth Hypothesis}

"There is a significant relation between ownership type (natural ownership) and the value of companies listed in Bombay`s stock exchange".
T-value for the degree of ownership concentration for natural shareholders is 2/37 (positive and significant). The significance level for the degree of ownership concentration for natural shareholders is $0 / 02$ which is less than $0 / 05$. Therefore, the null hypothesis is rejected and the alternative hypothesis is confirmed; therefore, considering the Beta value of $0 / 01$, there is a positive and significant relation between the degree of ownership concentration and value. The maximum value of VIF for the degree of shareholder's ownership is $1 / 71$, so the hypothesis is confirmed.

\section{Conclusion and Suggestion}

As the findings of the present study revealed, out of 8 research hypotheses, 6 hypotheses were confirmed and 2 hypotheses were rejected. This study investigated the effect of ownership structure as an internal mechanism of controlling company in capital market of Iran. Additionally, the new evidences about the effect of investors' ownership concentration, ownership type, and the effects pertained to institutional and natural shareholders' features in company's value were presented by the study which is as follows:

There is a positive and significant relation between ownership concentration and the value of companies listed in Tehran and Bombay stock exchanges, this findings is inconsistent with the finding reported by Mingazou and Yogdou (2007) investigating the effect of ownership structure I the value of company in capital market of Spain. So, in Tehran and Bombay stock exchanges, investors seeking higher return of their capital should pay attention to dispersion or concentration in investment selection,

There is no significant relation between institutional and natural ownership and 
the value of companies listed in Tehran stock exchange. There is a negative and significant relation between institutional ownership and value of companies listed in Bombay stock exchange. And also, there is a positive and significant relation between natural ownership and the value of companies listed in the stock exchange of this country. These findings are not consistent with the findings revealed $b$ Nicker and Nowisy (2006) examining the relation between institutional ownership and the value of company in New Zealand. In Tehran`s stock exchange, due to the fact that most of shareholders are state and the number of natural shareholders is very low, there is a relation between institutional and natural ownership and the value of companies but the relation is not significant. Hence, focusing on low efficacy of state ownership and slight ownership of natural shareholders, states and their dependent organizations, as the shareholders of state companies, need to help privatization process and financial structure reform, improve the performance, and increase economic units value. Therefore, unlike Tehran's stock exchange, a wide range of shareholders are in Bombay`s stock exchange and institutional shareholders are less. So, investors should consider natural shareholders` ownership to select investment.

\section{References}

Arosa, B.T., Iturralde, and Amaseda, (2010). Ownership structure and firm performance in non-listed firm: evidence from spain, Journal of Family Business Strategy, 1, 88-96.

Bai, C.Q., Liu, J., Lu, F., Song, and Zhang, J. (2004). Corporate governance and market valuation in china. Journal of Comparative Economics, 32, 599-616.
Ball, R., and Shivakumar, L. (2005). Earnings Quality in UK private firms: comparative loss recognition timeliness. Journal of Accounting and Economics, 39, 83-128.

Banerjee, A., Gokarn, S., and Pattanayak, M. (2009). Corporate Governance and Market Value: Preliminary Evidence from Indian Companies. Standard and Poor's Financial Services LLC. 1-10.

Berg, S.V. and Smith, S.K., (1978). CEO and Board Chairman: A Quantitative Study of Dual vs. Unitary Board Leadership, Directors and boards, 34-39.

Boubakri, B., Cosset, J.C., and Guedhami, 0. (2005). Postprivatization corporate governance: The role of ownership structure and investor protection. Journal of Financial Economics, 76, 369-399.

Bozec, Y, Bozec, R. (2007). Ownership concentration and corporate governance practices: substitution or expropriation effects? Canadian Journal of Administrative Sciences / Revue Canadienne des Sciences de l'Administration, 24(3), 182 -195.

Carter, D. A., Simkins, B. J. and Simpson, W.G. (2003). Corporate Governance, Board Diversity, and Firm Value, Financial Review, 38(1), 33-53.

Chang, J., and Sun, C. (2008). The Relation between Earning Information, Earnings Management and Corporate Governance in the Pre - and post - Sox Periods. Working Paper. SSRN.

Chioun, Jeng-Ren, Lin and Yi-Hua (2005). The Structure of Corporate Ownership: A Comparison of China and Taiwan's Security Markets.The Journal of American Academy of Business, Cambridge. 6(2), 123127. 
Clark and Worjcik (2005). Financial Valuation of German Model: The Negative Relationship between Ownership Concentration and stock, Market Returns, 1997-2001.

Demsetz, H. (1983). The structure of ownership and the thory of the firm. Journal of Law and Economics, 26, 375-390.

Demstez, H. and Bvillalonga (2001). Ownership structure and corporate performance, Journal of Corporate Finance, 7, 209-233.

Ding, Y., Hua, Y. and Junxi, Y. (2004). Ownership concentration and earnings management: A Comparison between Chinese Private and State- Owned Listed companies Electronic copy, Economic Geograohy. 81(1), 11-29.

Fama, E. and Jensen, M.(1983). Separation of ownership and control. Journal of Law and Economics, 26, 301-325.

Gedajlovic, E., and Shapiro, D. (2002). Ownership structure and firm profitability in japan. Academy of management journal, 45, 565-575.

Gompers, P., Ishii, J. and Metrick, A. (2003). Corporate governance and equity prices. Quarterly Journal of Economics 118, 107155.

Gunasekarage, A., Hess, K. and $\mathrm{Hu}, \mathrm{A}$. (2007). Theinfluense of the degree of state ownership and the ownership concentration on the performance of listed Chinese companies, Research in International Business and Finance, 21, 379-395.

Jensen, Michael C. and Meckling, William $\mathrm{H}$ (1976). Theory of the firm: Managerial Behavior, Agency costs and ownership structure. Journal of Financial Economics, 3, 305-360.
Justin T. Wang, Heibatollah Sami and Haiyan Zhou, (2009). Corporate governance and operating performance of Chinese listed firms. www.ssrn.com

Kapopoulos, P. and Lazaretou, S. (2007). Corporate ownership structure and firm performance: evidence from greek firms". Corporate governance: an international review, 15(2), 144-158.

King, M., and Santor, E. (2008). Family values: ownership structure performance and capital structure of Canadian firms, Journal of Banking and Finance, 32, 24232432.

La Porta, R., Lopez-de-Silanes, F. and Shleifer, A. (1999). Corporate ownership around the world. Journal of Finance, 54, 471-517. 18. Shleifer, A. and Vishny, R.W.(1997). A survey of corporate governance, Journal of Finance, 52.

La Porta, R., Lopez-de-Silanes, F. and Shleifer, A. (1999). Corporate ownership around the world. Journal of Finance, 54, 471-517.

Mat Nor, F., and Sulong, Z. (2010). Corporate Governance Mechanisms and Firm Valuation in Malaysian Listed Firms. Journal of Modern Accounting and Auditing, 6(1) , 18-36.

McConnell, J. and Servaes, H. (1990). Additional evidence on equity ownership and corporate value. Journal of Financial Economics, 27, 595-612.

McLuaghlin, S.D, (2006). English Language Proficiency, Occupational Characteristics and the Employment Outcomes of Mexican- American Men.Seattle: Batell Human A ffirs Research Center.

Minguez-vera, A. and Martin-ugedo, J.F. (2007). Does ownership structure affect value? A panel data analysis for the 
Spanish market. Journal Jnternational Review of Financial Analysis, 16, 81-98.

Morck, R., Shleifer, A., and Vishny, R. (1988). Management ownership and market valuation. Journal of Financial Economics, 20, 293-315.

Abidi, A. and Kapoor, S. (2009). Impact of dividend Policy on shareholders' value: A study of Indian firms, Jaypee Institute of Information Technology, Noida A-10, SECTOR 62, NOIDA, INDIA (12).

Navissi, F. and Niker, V. (2006). Institutional ownership and corporate value, Managerial Finance, 32(3), 247-256.

Rechner, P.L. and Dalton, D.R. (1991). CEO Duality and Organizational Performance: A Longitudinal analysis. Strategic Management Journal, 12(2), 155-60.

Rogers, P. and Dami, A. (2005). Corporate governance and ownership structure in Brazil: Causes and consequences, Social
Science Research Network, Electronic Paper Collection, New YORK, USA.

Ruiz- Mallorqui, M.V. and Santana-Martin. D.J. (2011). Dominant institutional owner and firm value, Journal of Banking \& Finance , 35, 118-129.

Schmid, M.M., Oesch, D., and Ammann, M. (2011). Corporate Governance and Firm Value: International Evidence. Journal of Empirical Finance, 18, 36-55.

WWW.

shirmard2005.blogsky.com/1386/04/27/ post-64.

$\mathrm{Xu}, \mathrm{X}$. and Wang, Y. (1999). Ownership structure and corporate governance in Chinese stock companies, China Economic Review, 10, 75-98.

$\mathrm{Xu}, \mathrm{X}$. , and Y, Wang, (1999). Ownership structure and corporate governance in Chinese stock companies. China economic review, 10, 75-98.

How to cite this article: Hossein Ali Jalali, Dr.Asghar Asadi, Dr.Seyed Yosef Ahadi Serkani, The Comparative Study of Ownership Structure Effects (Mix and Concentration) on the Value of Companies Listed in Tehran Stock Exchange (Iran) and Bombay Stock Exchange (India). International Journal of Advanced Studies in Humanities and Social Science, 2019, 8(1), 91-103. http://www.ijashssjournal.com/article 84112.html 